\title{
Economic implications of herbicide resistance and high labour costs for management of annual barnyardgrass (Echinochloa crus-galli) in Philippine rice farming systems
}

\author{
Jesusa C. Beltran ${ }^{*}, 1,2$, David J. Pannell ${ }^{1}$ and Graeme J. Doole ${ }^{1,3}$
}

\begin{abstract}
Implications of increasing labour costs and the development of herbicide resistance for profitable weed management in Philippine rice farming systems are investigated. The study employs RIMPhil (Resistance and Integrated Management in the Philippines), a bioeconomic simulation model developed to provide a comprehensive assessment of integrated weed management programmes for the control of annual barnyardgrass (Echinochloa crus-galli) in rice crops. Results indicate that herbicide application will become increasingly economically attractive, relative to manual weeding, as labour cost increases. This is important since urban migration in the Philippines continues to increase the scarcity of rural labour. Results also show that the onset of herbicide resistance results in substantial losses in farm profit. It is worthwhile for farmers to take management actions to prevent or delay the onset of herbicide resistance, provided that these changes are effective and not too costly. The study highlights the complexity of decision making about integrated weed management on rice farms in the Philippines.
\end{abstract}

Key words. Barnyardgrass; Bioeconomic model; Herbicide resistance; Integrated weed management; Rice farming system; Philippines.

\footnotetext{
* Corresponding author e-mail address: jcbeltran20@yahoo.com

Published as: Beltran, J.C., Pannell, D.J. and Doole, G. (2012). Economic implications of herbicide resistance and high labour costs for management of annual barnyardgrass (Echinochloa crus-galli) in Philippine rice farming systems, Crop Protection 31, 31-39.

${ }^{1}$ School of Agricultural and Resource Economics, Faculty of Natural and Agricultural Sciences, University of Western Australia, 35 Stirling Highway, Crawley, Western Australia 6009

${ }^{2}$ Philippine Rice Research Institute (PhilRice), Maligaya, Science City of Muñoz, Nueva Ecija, 3119, Philippines.

${ }^{3}$ Department of Economics, Waikato University, Private Bag 3109, Hamilton, New Zealand.
} 


\section{Introduction}

Rice is the staple food of more than 3 billion people worldwide, but growth rates in crop yields have fallen in recent times, declining by 82 per cent in 1991-2006, relative to the previous 15 years (Van Nguyen, 2009). Moreover, there is extensive evidence that environmental degradation (Pingali et al., 1997) and scarcity of appropriate land (FAO, 2002) and water resources (Rosegrant et al., 2002) are becoming increasingly important in limiting the capacity of rice production to meet global demand, which is expected to double by 2050 (Van Nguyen, 2009). This highlights a key need to promote the efficient production of rice within existing farming systems.

Manual weeding and flooding are traditionally used to restrict weed competition in rice farming systems. However, there has been a growing reliance on herbicides. Herbicide sales for rice crops globally grew at an average rate of more than 2 per cent year ${ }^{-1}$ from US\$741 million in 1980 to US\$1.34 billion in 2007 (Norton et al., 2010), exceeding growth rates reported for sales of insecticides $\left(0.9\right.$ per cent year $\left.{ }^{-1}\right)$ and fungicides $\left(0.2\right.$ per cent year $\left.{ }^{-1}\right)$. The global sale of herbicides for application in rice farming systems could reach US\$3 billion year $^{-1}$ by 2025 (Zhang et al., 2004). The trend in the Philippines from transplanting to directseeding rice has promoted the shift to herbicides, as initial flooding is not possible to control weeds in direct-seeded rice (Baltazar and De Datta, 1992). In addition, broadcast seed does not grow in consistent rows, making manual weeding less efficient (Marsh et al., 2005). Herbicides are easy to use, can achieve high rates of control with effective application, and are, overall, relatively inexpensive. On the other hand, the long-term economic benefits of alternative means of weed control can be influenced by a variety of factors, including labour costs.

Wage rates for farm workers in the Philippines have been increasing steadily over the last two decades (BAS, 2011). An important factor contributing to this increase has been the migration of farm workers, mostly unskilled, from agricultural to non-agricultural sectors (Habito and Briones, 2005). Indeed, in some areas of the country (e.g. Laguna and Bulacan), many farmers are finding it increasingly difficult to hire seasonal workers, resulting in higher farm workers' wage rates (Moya and Dawe, 2006). Higher labour costs could greatly influence the management decisions of producers, particularly those concerning the trade-off between the use of manual weeding and herbicides for weed control. 
Many studies have found that the onset of severe herbicide resistance in important crop weeds results in substantial economic losses (e.g. Pannell et al., 2004; Jones et al., 2006; Doole et al., 2009) This has been observed the world over, particularly in developed countries such as Australia and the United States of America (USA). The negative impacts of herbicide resistance in rice farming systems throughout developing countries, such as the Philippines, have thus far arguably been reduced since manual weeding can still be a profitable alternative to herbicide application. Nevertheless, the superiority of manual weeding is conditional on maintaining low levels of weed density in every cropping season and on sufficiently low labour costs. Moreover, a mechanical weeder can also be used as a substitute for herbicide application and manual weeding, although this method is typically less effective and requires row planting to facilitate its use.

High weed populations are commonly observed on most Philippine rice farms. With an increasing cost of labour, economic theory indicates that there is likely to be increased demand for substitute methods of weed control, such as herbicide application. Increasing herbicide use will promote the onset of herbicide resistance in rice farming systems, which could have a large adverse effect on farm income. Incidences of 2,4-D-resistant Sphenoclea zeylanica (Sy and Mercado, 1983) and butachlor+propanil-tolerant Echinochloa crus-galli (Juliano et al., 2010) have been reported in some important rice areas in the Philippines. Furthermore, in Central America, populations of propanil-resistant Echinocloa colona have been documented on many rice farms (Valverde et al., 2000). The objective of this study is therefore to investigate the impacts of increasing labour cost and the potential development of herbicide resistance on profitable strategies for the long-term management of weeds in rice farming systems. A simulation model of a representative rice farming system of the Philippines (Beltran et al., 2011) is used to investigate these problems within the context of the management of annual barnyardgrass (Echinochloa crus-galli), one of the most serious weed competitors of rice crops in the Philippines (Graf and Hill, 1992; De Dios et al., 2005). The model is based on an assumption that weeds other than annual barnyardgrass are controlled sufficiently in the field, which means that only two species of plants (i.e. rice and barnyardgrass) are competing for the limited resources. Where multiple weeds are present at high densities, results of the model would not be applicable. A modelling approach is highly appropriate given the inherent complexity of weed management decisions, particularly considering their dynamic nature and the integrated nature of many effective control 
strategies. A feature of this analysis is the use of extensive sensitivity analysis to assess how model output changes with perturbations to key parameters.

The aims of the paper are to evaluate the impacts of increasing labour cost and build up of herbicide resistance on the composition and profitability of alternative long-term weed management strategies in Philippine rice farming systems. It is structured as follows. Section 2 describes the model used in the analysis. The results of the analysis for labour cost are presented and discussed in Section 3, while those for herbicide resistance are presented and discussed in Section 4. Section 5 concludes the analysis.

\section{Tools and methods}

\subsection{Model outline}

The study employs the RIMPhil (Resistance and Integrated Management in the Philippines) model. This complex model is described in detail in Beltran et al. (2011) and readers are referred to this source for more information. RIMPhil is a bieconomic model, embedded in a decision support system (DSS), developed to analyse the economics of integrated weed management strategies for rice farming in the Philippines. It allows the analysis of strategies to control annual barnyardgrass, both in the presence and absence of herbicide resistance. The structure of the RIMPhil model is loosely based on that of the RIM (Resistance and Integrated Management) model, which has been developed in Western Australia to guide the management of annual ryegrass (Pannell et al., 2004) and wild radish weeds (Monjardino et al., 2003) in extensive mixed farming systems based mainly on cereal crops and livestock.

RIMPhil is a deterministic, dynamic model that allows the simulation of management strategies over a 20-year period. The incorporation of multiple years helps to describe the dynamic nature of weed populations and resistance development in a meaningful way. No automated optimisation procedure is used to identify the most profitable strategies, as done, for example, by Doole et al. (2009). Rather, a broad range of possible weed control strategies is evaluated through an extensive process of manual "trial and error" to identify near-optimal solutions. The preferred strategy is selected on the basis of producing the highest profit over the 20 -year period defined in the model. 


\subsection{Weed-crop competition}

In the RIMPhil model, the impacts of a rice crop's competitive ability on the number of seeds produced (seeds $\mathrm{m}^{-2}$ ) per barnyardgrass plant $\left(S_{W P}\right)$ is captured in the following equation:

$$
S_{W P}=S_{M S} \times\left(\frac{1}{a+W_{H B}+\left(b \times D_{D C}\right)}\right) \times \frac{W_{H B}}{W_{W S}} \times\left(1-D_{E}\right),
$$

where $S_{M S}$ represents maximum barnyardgrass seed production (seeds $\mathrm{m}^{-2}$ season $^{-1}$ ), $a$ signifies the barnyardgrass background competition factor $(\mathrm{BBCF})$ that is used to calculate the base level of intraspecies competition affecting weed seed production, $W_{H B}$ refers to the healthy equivalent barnyardgrass population density (plants $\mathrm{m}^{-2}$ ) before harvest, $b$ is the rice crop competition factor on barnyardgrass $(\mathrm{RCFB}), D_{D C}$ refers to the rice crop density depending on the seeding rate selected in the model, $W_{W S}$ is the number of barnyardgrass (plants $\mathrm{m}^{-2}$ ) surviving all of the treatments that occur before harvest, and $D_{E}$ represents the sub-lethal effect of selective herbicides that leads to lower seed production by weeds. The parameter values used in the model are as follows: $S_{M S}=48,000, a=23$, and $b=0.6 / 0.3$ for transplanted/direct-seeded rice, respectively.

Rice yield depends on the crop density and the competitive abilities of rice relative to barnyardgrass across planting techniques (Kropff and Lotz, 1993). In this model, assumed values used for standard crop yields are $5 \mathrm{t}$ per hectare (ha) for wet season and $6 \mathrm{t} \mathrm{ha}^{-1}$ for dry season. These values are the maximum attainable yields for certified inbred rice varieties in both seasons within a rice field with adequate fertility and no problems with water supply (Balisacan et al., 2006). The proportion of weed-managed yield that exists after accounting for the yield loss due to weed competition $\left(Y_{P R}\right)$ is calculated using:

$$
Y_{P R}=\frac{1+c}{D_{S R}} \times\left(\frac{D_{D C}}{c+D_{D C}+\left(d \times\left(W_{W S}+W_{W A}\right)\right)}\right) \times M_{Y L}+\left(1-M_{Y L}\right),
$$

where $c$ refers to the rice crop background competition factor $(\mathrm{RBCF}), D_{S R}$ represents a standard reference rice crop density (plants $\mathrm{m}^{-2}$ ) for each planting method, $D_{D C}$ refers to the actual rice crop density (plants $\mathrm{m}^{-2}$ ) that depends on the seeding rate selected by the user, $d$ 
signifies the barnyardgrass competition factor in the rice crop (BCFR), $W_{W S}$ is the number of barnyardgrass plants (plants $\mathrm{m}^{-2}$ ) just before harvest, $W_{W A}$ refers to the number of barnyardgrass plants (plants $\mathrm{m}^{-2}$ ) that must be added to $W_{W S}$ to account for the yield loss that will be incurred with the late removal of weeds, and $M_{Y L}$ represents the maximum proportion of grain yield loss at high weed densities.

Assumed values for RBCF are 3.5 for both crop establishment methods, while the values of BCFR are 180 per cent and 360 per cent for transplanted and direct-seeded rice, respectively. The estimated values of $W_{W A}$ are calculated by multiplying the estimated proportion of weeds that are killed by the total number of weeds removed from day 31 after transplanting/directseeding (DAT/DAS) until before crop harvest, with a default value of 10 per cent. Moreover, the value of $M_{Y L}$ varies according to the planting methods defined in each cropping season. Based on Moody (1990), the estimated values of $M_{Y L}$ that are used in the model during the dry season are 61 per cent for transplanted rice and 64 per cent for direct wet-seeded rice. On the other hand, the $M_{Y L}$ values for the wet season are 56 per cent and 62 per cent for transplanted and direct wet-seeded rice, respectively. Densities of 75 and 150 plants $\mathrm{m}^{-2}$ are the values that are used for the standard reference level of rice crop density $\left(D_{S R}\right)$ for transplanted and direct-seeded rice crops, respectively. These are based on PhilRice recommended seeding rates of 20-40 kilogram $(\mathrm{kg}) \mathrm{ha}^{-1}$ for transplanted rice (PhilRice, 2000) and 40-80 $\mathrm{kg} \mathrm{ha}^{-1}$ for direct wet-seeded rice (PhilRice, 2001). The value of actual crop density $\left(D_{D C}\right)$ depends on the selected seeding rate options included in the model: 50, 100, 150,200 , and $300 \mathrm{~kg} \mathrm{ha}^{-1}$.

\subsection{Weed control options}

There are a total of 49 individual weed-control treatments included in the RIMPhil model. These treatments are divided into two general groups: herbicide and non-herbicide weed controls. There are 29 herbicide options included in the model and these are sorted into two separate groups: selective herbicides (24) and non-selective herbicides with cultural methods (2). There is also provision for three user-defined selective herbicides. Selective herbicide treatments in the model are grouped according to their time of application, these being: (1) pre-emergence herbicides with application time from 0-6 days after seeding, (2) early postemergence herbicides with application times from 7-15 days after seeding, and (3) late post- 
emergence herbicides with application time from 16-30 days after seeding (De Datta and Baltazar, 1996). On the other hand, non-herbicide treatments included in the model are either cultural or manual methods including stale-seedbed management (this involves repeated plowing and harrowing of the land during the fallow period to stimulate weed growth), land cultivation, water management, manual weeding, and mechanical weeding. Among these treatments, manual weeding, herbicides application, and mechanical weeding represent the primary means of weed control for rice crops. The most profitable weed control strategy usually involves a choice from these methods (Beltran et al., 2011). Detailed information regarding these options is presented in Beltran et al. (2011).

\subsection{Herbicide resistance}

The RIMPhil model excludes the detailed simulation of the population genetics of resistance development given that there exists insufficient information to accurately portray this process for the multiple herbicides incorporated in the model. Instead, the process is represented in a way that is both computationally efficient and consistent with the way herbicide resistance affects producers. A maximum number of applications is specified for each herbicide, above which the herbicide no longer is effective. Specification of herbicides as a finite resource is consistent with the stylised facts of resistance development and allows users to broadly state whether herbicide resistance cannot occur, has occurred, or can occur over the planning horizon. Comprehensive follow-up hand weeding is available as an option and, if selected, completely counters any selection pressure for herbicide resistance in that year.

Based on discussions with weed scientists, for this analysis the assumed number of applications or the label recommended dose of each group of herbicides available prior to the onset of herbicide resistance in the standard model is as follows:

- 12 doses of each type of Groups A (aryloxy phenoxy propionate), B (sulfonylureas), and $\mathrm{C}$ (benzothiadiazones) herbicides;

- 16 doses each of Groups K1 (dinitroaniline) and O (phenoxy-carboxylic-acids) herbicides; and

- 20 doses each of Groups D (bipyridyliums), E (oxadiazole), G (Glycines), K3 (chloroacetamide), and $\mathrm{N}$ (thiocarbamate) herbicides. 
A wide selection of non-herbicide weed control options is also included in the model. This permits the user to identify profitable substitutes as herbicide efficacy is lost.

The structure of the model allows selection of a rotation from year to year of herbicides of different modes of action. This extends the life of any herbicide group simply by reducing its frequency of use. It is assumed that such rotations do not result in additional applications of a herbicide group being possible, which is consistent with the assumption that the herbicides do not reduce weed numbers to zero in any year.

The model allows herbicides to be selected as part of an integrated weed management strategy, in combination with non-herbicide treatments. Incorporating non-chemical control methods may also extend the life of a herbicide by allowing it to be applied less frequently, but it is assumed that the non-chemical methods do not cause extinction of the weed, so they do not increase the number of herbicide applications that are possible prior to the onset of resistance.

\subsection{Economics}

The model calculates the costs and revenues for each simulated strategy. The model uses discounting to compare costs and benefits that occur at different times (Pannell, 2006). These discounted costs and benefits are summed to calculate the Net Present Value (NPV) using a real discount rate of 6 per cent. The model also accounts for long-term trends in real prices and yields in the calculation of the NPV. Economic returns are mainly reported below in terms of the equivalent annual profit (EAP), or annuity. The EAP is a constant annual profit value that would provide the same NPV as the observed sequence of benefits and costs (Pannell, 2006).

Costs included in the model are: weed control costs (chemical and non-chemical weed control costs), and non-weed control costs (inputs and other production costs). The costs of crop yield loss due to the phytotoxicity effect of chemical use and a penalty for using poor quality seeds are also represented in the model. Economic returns from crops are mainly based on crop yields and sale prices. 


\subsection{Model validation}

Appropriate verification of a model involves reflection on the suitability of model structure, inputs, and outputs (Naylor and Finger, 1967) and whether it is "fit for its purpose" (McCarl and Apland, 1986). The structure of the model and the parameters that have been utilised within RIMPhil are based on the best information available pertaining to rice farms in the Philippines. Weed population dynamics and control efficacy parameters have been drawn from extensive literature review and discussion with experienced weed scientists. The use of expert opinion to elicit appropriate functional form relationships and parameter values is a critical aspect of developing many bioeconomic models, as it extremely rare for ideal validation data to be available in sufficient amounts given the large amount of information that comprehensive system models require and the limited scope of most experimental studies. The biological output of the Western Australian version of RIM (Pannell et al., 2004) has been validated against field data (see Draper and Roy, 2002). The output of RIMPhil has not been validated in a similar way given the absence of equivalent information for the farming system described, particularly over a series of years. This is indeed typical of most bioeconomic models (McCarl and Apland, 1987). However, after extensive review, RIMPhil has been judged by weed scientists to provide a meaningful description of annual barnyardgrass dynamics in this farming environment.

\subsection{Model runs}

Section 3 reports and discusses model output. The profitability of each strategy is measured based on the EAP ha-1 over a 20 -year planning horizon, and all monetary values are presented in US dollars. For the purpose of this study, the exchange rate used for converting Philippine peso (PHP) into US dollar is US $\$ 1=$ PHP45.

All weed-control scenarios are based on direct-seeding for crop establishment in both cropping seasons (wet and dry) over 20 years. The use of direct-seeding is motivated by the popularity of this method as a labour-saving technology. Direct-seeding will likely dominate rice production when labour costs increase substantially. In addition, the use of direct-seeding typically results in a higher weed density than in transplanted crops, so weed-control becomes a more important issue. 
Standard assumptions in the analysis are initial seed density of 200 seeds $\mathrm{m}^{-2}$ and no initial herbicide resistance. In the simulations, resistance develops over time as the available stock of herbicide applications for each group of herbicides is exhausted. Note that the term herbicide is used throughout this paper in reference to the application of post-emergence selective herbicides (POST) unless otherwise stated. The use of a mechanical seeder (i.e. drumseeder) for sowing the rice seeds is necessary to facilitate the use of manual weeding when direct-seeding is used.

The impacts of increasing labour cost on the most-profitable weed control strategy is evaluated in Section 3 for scenarios with differing levels of weed density and different weed threshold levels. The weed threshold represents the number of weed plants in the field where no weed control is undertaken unless the threshold is exceeded. Three labour prices are used in the analysis, these being: (1) current labour cost (base-case); (2) higher labour cost (100 per cent increase in the current price), and (3) very high labour cost (200 per cent increase in the current price). Based on the increasing trend observed in the nominal wage rate in the country, 100 and 200 per cent increases in the current labour price are realistic values to use to demonstrate the potential implications of high labour cost in determining the optimal longterm weed treatment strategy. It is expected that they could be observed within 5 to 10 years.

The implications of herbicide resistance are investigated in Section 4 through the manipulation of the availability of selective herbicides. As herbicide resistance develops, chemicals that are effective for the control of barnyardgrass become less available. Two similar rice fields that differ in their herbicide resistance status are used in the analysis presented in Section 4. The first one has no resistance at the start of the planning period, but resistance may develop over the subsequent 20-year horizon if all of the allowable herbicide applications for a chemical group are exhausted. The standard levels of herbicide availability that are represented are 12 doses each for Groups A and B herbicides. In comparison, the other field has a severe herbicide resistance problem and, for illustrative purposes, the farmer is assumed not to apply herbicides from Groups A and B because of their lack of efficacy. In the following evaluations, the permissible numbers of applications for other groups of herbicides are held constant at the levels noted earlier and no constraints are placed on the use of non-herbicide treatments.

The likelihood that there will be sufficient herbicide use to cause resistance in the rice fields depends on the labour cost and weed threshold level. Comparative economic returns and 
optimal weed control treatments with and without herbicide resistance are evaluated and compared in two different scenarios in Section 4. These scenarios are: (1) very high labour cost $\left(\mathrm{US} \$ 17\right.$ manday $\left.^{-1}\right)$ with low weed threshold level $\left(0.1\right.$ plants $\left.\mathrm{m}^{-2}\right)$, and (2) very high labour cost (US\$17 manday ${ }^{-1}$ ) coupled with high weed threshold level (2 plants $\mathrm{m}^{-2}$ ). A sensitivity analysis is conducted to investigate whether the relative cost of herbicide resistance is robust to changes in the most important parameters of the model.

\subsection{Sensitivity analysis}

A sensitivity analysis is used to investigate how model output changes with perturbations to key parameters. The sensitivity analysis is conducted in this study utilising one method (Strategy B) suggested by Pannell (1997). This procedure involves:

- Identification of the parameters of the model that are subject to most uncertainty and may influence model results.

- Specification of low, standard, and high values for each of the identified parameters.

- Use of sensitivity indices to assess the responsiveness of model results to changes in key coefficients within the range of parameter values specified in Step 2.

- Design and conduct of a modelling experiment. This involves a complete factorial experiment being carried out for the most-responsive parameters.

A sensitivity index indicates the change in key model output with respect to a parameter change. It is calculated for each uncertain parameter based on the range of values specified for each key coefficient in Step 2 of the procedure. A range of sensitivity indices can be used, but the sensitivity index $(S I)$ employed here is calculated using the following formula:

$$
S I=\left(\frac{P_{\max }-P_{\min }}{P_{s t}}\right)
$$

where $P_{\max }$ is the annual equivalent profit of the optimal weed management strategy for each scenario when the parameter in question is set at its maximum value, $P_{\min }$ is the annual equivalent profit for the minimum parameter value, and $P_{s t}$ is the annual equivalent profit for the standard value of the parameter. Annual equivalent profit is identified as the key output of the model because it reflects the overall value of the long-term weed management strategies. 
This method is used in Monjardino et al. (2003) for conducting sensitivity analysis using the RIM model.

The most important uncertain model parameters identified in the sensitivity analysis performed in this study have an absolute sensitivity index value equal to or greater than 0.2. This indicates that each perturbation incurs at least a US $\$ 20 \mathrm{ha}^{-1}$ change in EAP per cropping season, or about US $\$ 40 \mathrm{ha}^{-1}$ annually over 20 years. The following parameters incur changes that have this impact or greater: (a) base yield with no weeds present, (b) net sale price of rice crop, (c) barnyardgrass seed production, (d) maximum barnyardgrass seed production, (e) rice crop competition factor on barnyardgrass, and (f) discount rate. Table 1 shows the low, standard and high values of these key parameters. The low and high values for these parameters are used to implement complete factorial experiments to investigate the implications of parametric change and uncertainty on model outputs. A complete factorial experiment involves the computation of model output for every possible combination of low and high values estimated for each of the six parameters listed above. The complete set of model runs consists of $2^{6}(64)$ solutions.

[Insert Table 1 near here]

\section{Impacts of high labour cost}

This section reports and discusses the implications of model results concerning the impacts of increasing labour cost for the management decisions of rice farmers in the Philippines, particularly those concerning the trade-off between the use of manual weeding and herbicides to control weeds.

\subsection{Weed density and labour cost}

Model results regarding the impacts of labour costs across different weed density levels on the most profitable weed control methods are presented here. Table 2 shows the economic implications of timely manual weeding and use of post-emergence selective herbicides in one cropping period under different weed densities across different labour costs. Under current labour costs (base-case), with low weed density, the treatment costs for manual weeding (US\$34 ha ${ }^{-1}$ ) are slightly higher (by about 6 per cent) than for herbicide application (US\$32 $\mathrm{ha}^{-1}$ ). However, the net returns for manual weeding are slightly higher (US\$599 ha ${ }^{-1}$ 
compared to US $\$ 595 \mathrm{ha}^{-1}$ ) due to superior weed control. Holding labour costs constant at US\$5 and increasing the initial weed density, the cost of manual weeding rises substantially while the cost of herbicide application is unchanged. This is primarily because the cost of manual weeding depends directly on weed numbers, whereas the cost of herbicides does not. Accordingly, the returns of herbicide application are superior at all weed densities above 5 plants $\mathrm{m}^{-2}$. The profit advantage of herbicide is positively related to the weed density.

[Insert Table 2 near here]

Now examining the impact of labour costs, compare results across the columns of Table 2. With increased labour cost, herbicide application is superior to manual weeding even at the lowest weed density (by US\$25 ha- or US\$54 ha ${ }^{-1}$ for the two higher labour costs). Finally, there is a positive interaction between high labour costs and high weed density, so that the profit advantage of herbicides is much greater again when both are present. At the highest weed density and the highest labour cost, herbicide application is approximately 80 per cent (about US\$200 ha-1) more profitable than manual weeding.

\subsection{Weed threshold and labour cost}

The impacts of labour costs on the optimal weed management strategy also vary across different weed threshold levels. In the Philippines, high weed populations are a common situation on most rice farms, implying that, if farmers use a threshold, it is well above the optimal level. From experimenting with the model, the optimal weed threshold level is found to be significantly lower than commonly assumed; a value of 0.1 plant $\mathrm{m}^{-2}$ is used. This has important implications for labour cost and the relative profitability of manual weeding and herbicide weed control methods. To illustrate this case, three different labour cost scenarios are presented below.

Figure 1 illustrates the profit difference between a weed strategy with manual weeding as the only direct means of weed control over 20 years (i.e. manual weeding strategy) and a weed strategy involving herbicide application for some cropping periods (i.e. herbicide application strategy) under different weed threshold levels. Under current labour cost (US\$5), using an optimal weed threshold level $\left(0.1\right.$ plants $\left.\mathrm{m}^{-2}\right)$, manual weeding appears to be slightly more profitable due to its lower cost, provided it is undertaken on time. 
[Insert Figure 1 near here]

On the other hand, holding labour costs constant at its current level and increasing the weed threshold level above its optimal level, the level of profit computed for the two strategies starts to diverge. Herbicide application becomes a more profitable strategy than manual weeding, although their profit difference is still not substantial. These findings imply that if labour costs remain at their current levels across all weed threshold levels, herbicide application and manual weeding are good substitutes, provided that weeds are maintained at low densities.

Now evaluating the effects of labour cost under different weed threshold levels, compare the two profit lines in Figure 2. In this scenario, the labour cost is assumed to increase by 100 per cent. With increases in labour cost, results show that the profit lines diverge more than in the previous graph that presents a scenario involving the current labour cost (Figure 1). It demonstrates that the profit difference between manual weeding and herbicide application at all weed threshold levels increases with increasing labour cost.

[Insert Figure 2 near here]

There is a positive interaction between labour demand and weed threshold level, as more effort is required to remove weeds manually when high weed populations are present. High labour costs make the manual weeding method very expensive as weed thresholds increase. As a result, herbicide application becomes superior to manual weeding when there is both a high labour cost and a high weed threshold level. At the highest labour cost considered (i.e. 200 per cent increase in the current price), across all of the weed threshold levels, the profit advantage of herbicide over manual weeding is much greater (Figure 3). Therefore, reliance on post-emergence selective herbicides under optimal management rises substantially with increasing weed threshold levels and as the cost of labour increases.

[Insert Figure 3 near here]

Overall, these findings highlight the optimality of herbicide application, relative to manual weeding, as the primary form of weed control in rice farming systems if labour cost increases, or similarly, labour resources become more scarce. However, if labour costs increase, greater reliance is placed on herbicides and therefore the probability that herbicide 
resistance becomes more widespread also increases. This situation is further aggravated if weeds are not controlled optimally because a higher weed population promotes seed production that, in turn, makes weed-crop competition more intense.

The results in this section highlight the importance of considering labour constraints in the evaluation of optimal weed management strategies. This is especially the case in developing countries where employment in agricultural sectors is decreasing.

\subsection{Sensitivity analysis}

The sensitivity analysis on the impact of labour cost involves the computation of complete factorial experiments for model results involving the six most important parameters identified in Section 2.7. The complete set of model runs for the sensitivity analysis for each scenario consists of $2^{6}$ (64) solutions. The solutions presented here are for optimal weed control strategies for a scenario of very high labour cost (i.e. 200 per cent increase in the current price) and optimal weed threshold level $\left(0.1\right.$ plant $\left.\mathrm{m}^{-2}\right)$. The very high labour cost is used for illustration because this is the price setting where the economic implications of manual weeding and herbicide application strategies are most significant. Note that the methods of weed control adopted in both cases are held constant over 20 years, and therefore negative profits are also observed in some scenarios.

Figure 4 illustrates the profit difference between herbicide application and manual weeding. (Positive differences indicate that herbicides are superior.) About 60 per cent of the scenarios investigated have a profit difference of zero, or close to zero. However, a minority of scenarios have high profit benefits for herbicides so, across all scenarios, the average profit advantage of herbicide application over manual weeding is around US\$8,000 ha $\mathrm{ha}^{-1}$ These results support the finding that when labour cost is high and a high weed threshold is used, herbicide application is likely to be the preferred strategy. Even in the scenarios that are least favourable for herbicides, it performs no worse than manual weeding.

[Insert Figure 4 near here]

\section{Impacts of herbicide resistance}

This section reports and discusses the implications of model results concerning the impacts of herbicide resistance for the management decisions of rice farmers in the Philippines. 


\subsection{Very high labour cost under optimal weed density}

Results show that the optimal strategies generated for both scenarios with and without herbicide resistance have almost the same average weed density over 20 years, although the total number of weed control options used is slightly higher when herbicide-resistance is present (Table 3). For example, as use of Group A and B herbicides drops from 12 doses each (i.e. zero resistance case) to zero applications (i.e. full resistance case), the use of manual weeding increases from 25 to 28 events. Adoption of thorough land preparation also increases from 6 to 8 applications. Nevertheless, the two cases involve very similar types of weed treatments over a 20-year planning horizon. These results are consistent with the findings of other authors (e.g. Monjardino et al., 2004 a, b; Pannell et al., 2004; Doole et al., 2009; Doole and Revell, 2010) who also found that (a) there was an insignificant difference in optimal weed density between scenarios in which herbicide resistance is present and those in which it is not, and (b) the number of weed control treatments increased under profitable management in the presence of herbicide resistance. These additional weed control strategies help to reduce competition from weeds given the lower availability of chemicals for effective control. These strategies also help to reduce the difference in weed densities between the two scenarios.

\section{[Insert Table 3 near here]}

With the presence of herbicide resistance, the net returns achieved over 20 years slightly decreases - by about 1.5 per cent (Table 3 ). The economic losses are due to the high cost of manual weeding and additional treatment costs incurred by the presence of resistance. Nevertheless, the economic costs of herbicide resistance are not high provided that weeds are well-managed, even if the cost of labour is increased. As mentioned above, less labour is required for weed control at lower weed densities. As shown in Table 2, the treatment cost of manual weeding increases as the weed density increases, and this cost is further intensified by an increasing price of labour. This finding is investigated further in the next subsection.

\subsection{Very high labour cost under high weed density}

The impact of herbicide resistance is more evident if a high cost of labour is coupled with a high weed control threshold. Table 4 shows that EAP declines from US\$1,260 to US\$1,178 $\mathrm{ha}^{-1}$ year $^{-1}$, or by about 7 per cent, when applications of Groups A and B selective herbicides 
are completely restricted to simulate resistance development. With the onset of resistance, manual weeding is required in place of herbicides to maintain a low number of seedproducing weed plants. However, if there is a high weed density (due to a high weed control threshold) manual weeding is so expensive that it would cause a substantial reduction in profit with a high labour price. Thus, this result reinforces the conclusion that herbicide application becomes the most attractive option for controlling weeds in rice farming systems if the cost of manual weeding is high.

[Insert Table 4 near here]

Increases in total weed management cost for the two herbicide resistance cases are also brought about by the additional weed treatments required to maintain effective control of the weed. For instance, it is optimal to employ water management, thorough land preparation, and application of other groups of selected herbicides in almost every cropping season throughout the 20-year horizon to achieve high weed control when the weed threshold level increases to 2 plants $\mathrm{m}^{-2}$.

Overall, the model results show that the optimal weed strategies with and without herbicide resistance provides almost the same average weed density over the planning period. Therefore, the profit difference between the two cases is mainly due to differences in total weed treatment costs rather than to differences in weed competition.

It appears that the onset of herbicide resistance will result in only modest reductions in the incomes of Filipino rice farmers. Nevertheless, there may be economic incentives for farmers to try to prevent or delay development of resistance. The robustness of these model runs are tested in the next subsection.

\subsection{Sensitivity analysis}

This sensitivity analysis is carried out to test the robustness of results indicating the negative impact on profits following the onset of herbicide resistance. The same procedure for sensitivity analysis used in Section 3 is adopted here. Profit differences with and without resistance scenarios are estimated under very high labour cost and high weed threshold level. In all sensitivity scenarios, the six most-sensitive parameters are varied in a complete factorial design, while all other parameters are kept fixed at their standard values. Note that 
the most profitable weed control strategies over 20 years are determined through exhaustive experimentation with the model.

Figure 5 demonstrates that the onset of herbicide resistance often results in a loss in farm profit, but that in some scenarios, the loss is only modest. About 50 per cent of the scenarios examined have a profit loss of US\$60 ha year $^{-1}$ or less over the 20 years. Across all scenarios, an average profit loss of about US\$100 ha-1 year-1 is incurred due to herbicide resistance. This represents about a 17 per cent reduction in the average net profit per cropping season (approximately US\$600 $\mathrm{ha}^{-1}$ year $^{-1}$ ) from rice farming, which, while possibly not devastating, would be a serious loss for Filipino farmers.

[Insert Figure 5 near here]

As noted earlier, the results presented have been for direct-seeded rice, since this is becoming more popular and is likely to result in more serious weed management problems. Results not presented here show that, under a transplanted system, weed management costs would generally be lower, but otherwise conclusions would be broadly similar. Increasing labour costs over time are likely to continue the trend towards reliance on herbicides for weed control. Herbicide resistance in transplanted rice will have widely varying impacts on farmer incomes depending on the scenario, but on average would cause serious income losses.

Also not made explicit in the results presented are the differences between weed-control treatments in wet and dry seasons. Weeds typically occur at higher densities during the wet cropping season and so require a greater number and cost of weed control treatments relative to dry cropping season.

\section{Conclusions}

The implications of high labour cost and build up of herbicide resistance for optimal longterm weed management have been examined in this paper, using the RIMPhil model. Results indicate that the use of post-emergence selective herbicides is generally more profitable than manual weeding when weed populations are high, as the cost of manual weeding is positively related to weed numbers. This result is supported by an extensive sensitivity analysis, which shows that herbicide is substantially more profitable in about 60 per cent of scenarios, and is less profitable in any other scenarios. 
Model runs with and without herbicide resistance included clearly demonstrate that the onset of herbicide resistance poses economic challenges to farmers. Across all scenarios of a sensitivity analysis, an average profit loss of about US $\$ 100 \mathrm{ha}^{-1}$ year $^{-1}$ is incurred due to herbicide resistance. However, these results are conditional on the assumed level of labour cost, which is very high compared to standard levels. This high labour cost is considered realistic within the next decade or two.

Results suggest that it may be worthwhile for farmers to take management actions to attempt preventing or delaying the onset of herbicide resistance, provided that these changes are effective and not too costly. This has important implications for weed scientists, extension agents, consultants and policy makers - there may be benefits from development and promotion of new or improved technologies and systems for weed control.

Overall, this analysis indicates that increasing labour costs in the Philippines will likely promote herbicide application. Moreover, the greater intensities of chemical application for weed control could increase resistance development, which is demonstrated to reduce farm profit. The degree to which these findings are applicable to rice farming systems in other regions of Asia is worthy of further research.

\section{Acknowledgements}

The authors are thankful to PhilRice, Australian Centre for International Agricultural Research (ACIAR), and the School of Agricultural Resource Economics at the University of Western Australia (UWA) for funding this research. We are also grateful for advice, information, and assistance from weed experts in the Philippines: Joel Janiya, Edwin Martin, Lani Juliano, and Madonna Casimero.

\section{References}

Beltran, J.C., Pannell, D.J., Doole, G. J., and White, B., 2011. RIMPhil: a bioeconomic model for integrated weed management of annual barnyardgrass (Echinochloa crus-galli) in Philippine rice farming systems. Working Paper 1112, School of Agricultural and Resource Economics, The University of Western Australia, Crawley, Australia.

Balisacan, A.M., Sebastian, L.S. and Associates., 2006. Securing Rice, Reducing Poverty: Challenges and Policy Directions. BAR-PhilRice Publication, Philippines. 
BAS, 2011. Bureau of Agricultural Statistics (BAS), CountrySTAT Philippines. [Online]. Available from URL: http://www.countrystat.bas.gov.ph [accessed 10 January 2011].

Baltazar, A.M. and De Datta, S.K., 1992. Weed management in rice. Weed Abstracts 41, 495-508.

De Datta, S.K. and Baltazar, A.M., 1996. Integrated weed management in rice in Asia. In: Naylor, R. (Ed.), Herbicides in Asian Rice: Transitions in Weed Management. Palo Alto (California): Institute for International Studies, Stanford University and Manila (Philippines): International Rice Research Institute, pp. 145-166.

De Dios, J.L., Javier, E.F., Malabayabas, M.D., Casimero, M.C. and Espiritu, A.J., 2005. An overview of direct-seeding for rice crop establishment in the Philippines. In: Toriyama, K., Heong, K.L. and Hardy, B. (Eds.), Rice is Life: Scientific Perspective for the 21 st Century. Proceedings of the World Rice Research Conference. IRRI and Japan International Research Center for Agricultural Sciences (CD-ROM), 4-7 November 2004, Tokyo and Tsukuba, Japan, pp. 189-192.

Doole, G.J. and Revell, C.K., 2010. Delayed pasture germination allows improved rigid ryegrass (Lolium rigidum) control through grazing and broad-spectrum herbicide application. Crop Prot. 29, 153-162.

Doole, G.J., Pannell, D.J. and Revell, C.K., 2009. Economic contribution of French serradella (Ornithopus sativus Brot.) pasture to integrated weed management in Western Australian mixed-farming systems: an application of compressed annealing. Aust. J. Agric. Resour. Econ. 53, 193-212.

Draper, A.D., and Roy, B., 2002. Ryegrass RIM model stands the test of IWM field trial data. AgriBusiness Crop Updates 2002, pp. 49-50.

Food and Agricultural Organisation (FAO), 2002. Crop production. World agriculture: towards 2015/2030. Summary report. [Online]. Available from URL: http://www.fao.org/docrep/004/y3557e/y3557e08.thm [accessed 5 August 2011].

Graf, B. and Hill, J.E., 1992. Modelling the competition for light and nitrogen between rice and Echinochloa crus-galli. Agric. Syst. 40, 345-359.

Habito, C.F. and Briones, R.M., 2005. Philippine agriculture over the years: performance, policies and pitfalls. Paper presented at the conference entitled "Policies to Strengthen Productivity in the Philippines". Sponsored by the Asia-Europe Meeting (ASEM) Trust Fund, Asian Institute of Management Policy Center, Foreign Investment Advisory Service, PIDS and the World Bank, 27 June 2005, Makati City, Philippines. 
Kropff, M.J. and Lotz, L.A.P., 1993. Empirical models for crop-weed competition interactions. In: Kropff, M.J. and van Laar, H.H. (Eds.), Modelling Crop-weed Interactions. CAB International, Wallingford, Oxon OX10 8DE, UK, pp. 9-23.

Marsh, S.P., LLewellyn, R.S., Casimero, M.C. and Cataquiz, G.C., 2005. Direct-seeding of rice and herbicide use in the Philippines: implications for weed management. Paper Presented at the 49th Australian Agricultural and Resource Economics Society Conference, 8-11 February 2005, Coffs Harbour, New South Wales.

McCarl, B.A., and Apland, J.D., 1986. Validation of linear programming models. South. J. Agr. Econ. 18, 155-164.

Monjardino, M., Pannell, D.J. and Powles, S.B., 2003. Multispecies resistance and integrated management: a bioeconomic model for integrated management of rigid ryegrass (Lolium rigidum) and wild radish (Raphanus raphanistrum). Weed Sci. 51, 798-809.

Monjardino, M., Pannell, D.J., and Powles, S.B., 2004a. The economic value of pasture phases in the integrated management of annual ryegrass and wild radish in a Western Australian farming system. Aust. J. Exp. Agric. 43, 1-7.

Monjardino, M., Pannell, D.J., and Powles, S.B., 2004b. The economic value of haying and green manuring in the integrated management of annual ryegrass and wild radish in a Western Australian farming system. Aust. J. Exp. Agric. 44, 1195-1203.

Naylor, T.H. and Finger, J.M., 1967. Verification of computer simulation models. Manage. Sci. $14,92-101$.

Norton, G. W., Heong, K. L., Johnson, D., Savary, S., 2010. Rice pest management: issues and opportunities. In: Pandey, S., Byerlee, D., Dawe, D., Dobermann, A., Mohanty, S., Rozelle, S. and Hardy, B. (Eds.), Rice in the Global Economy: Strategic Research and Policy Issues for Food Security. Los Baños (Philippines): International Rice Research Institute, pp. 297-332.

Moody, K., 1990. Yield losses due to weeds in rice in the Philippines. Crop Loss Assessment in IRRI. International Rice Research Institute, Philippines, pp. 193-202.

Moya, P.F. and Dawe, D.C., 2006. Mechanization and saving labor are the keys to making rice more competitive. In: Dawe, D.C., Moya, P.F. and Casiwan, C.B. (Eds.), Why Does the Philippines Import Rice?, Meeting the Challenge of Trade Liberalization. IRRI (Los Baños, Laguna) and PhilRice (Science City of Muñoz), Manila, Philippines, pp. 69-72. 
Jones, R.E., Cacho, O. and Sinden, J., 2006. The importance of seasonal variability and tactical responses to risk on estimating the economic benefits of integrated weed management. Agric. Econ. 35, 245-256.

Juliano, L.M., Casimero, M.C. and Llewellyn, R. (2010). Multiple herbicide resistance in barnyardgrass (Echinochloa crus-galli) in direct-seeded rice in the Philippines. Int. J. Pest Manage. 56, 299-307.

Pannell, D.J., 1997. Sensitivity analysis of normative economic models: theoretical framework and practical strategies. Agric. Econ. 16, 139-152.

Pannell, D.J., 2006. Avoiding simplistic assumptions in discounting cash flows for private decisions. In: Pannell, D.J. and Schilizzi, S.G.M. (Eds.), Economics and the Future, Time and Discounting in Private and Public Decision Making. Edward Elgar Publishing, Inc, Willian Pratt House, 9 Dewey Court, Northampton, Massachusetts 01060, USA, pp. 26-36.

Pannell, D.J., Stewart, V., Bennett, A., Monjardino, M., Schmidt, C. and Powles, S.B., 2004. RIM: a bioeconomic model for integrated weed management of Lolium rigidum in Western Australia. Agric. Syst. 79, 305-325.

PhilRice, 2000. $40 \mathrm{~kg}$ certified seeds per hectare. Rice Technology Bulletin 2000 No. 26. Philippine Rice Research Institute (PhilRice), Philippines.

PhilRice, 2001. Wet-seeded rice production. Rice Technology Bulletin 2001, No. 41. Philippine Rice Research Institute (PhilRice), Philippines.

Pingali, P.L., Hossain, M. and Gerpacio, R.V., 1997. Asian Rice Bowls: The Returning Crisis? CAB International in association with International Rice Research Institute (IRRI).

Rosegrant, M. W., Cai, X., Cline, S. A., 2002. World Water and Food to 2025: Dealing with Scarcity. International Food Policy Research Institute, Washington D.C.

Sy, S.J. and Mercado, B.L. (1983). Comparative response to 2,4-D of Sphenoclea zeylanica collected from two locations. Phil. Weed Sci. 10, 90.

Valverde, B.E., Riches, C.R. and Caseley, J.C. (2000). Prevention and Management of Herbicide Resistant Weeds in Rice: Experiences from Central America with Echinochloa colona. S. A. Grafos, Cartago, Costa Rica.

Van Nguyen, N. (2009). Sustainable intensification of rice production for food-a summary report, International Rice Commission, Food and Agriculture Organisation, Rome.

Zhang, W., Qi, Y. and Liu, Y. (2004). Forecasting trend of rice production of the world and regions. In: Fischer, T., Turner, N.C., Angus, J., McIntyre, L., Robertson, M., Borrell, 
A. and Lloyd, D. (Eds.), New Directions for a Diverse Planet. Proceedings for the 4th International Crop Science Congress, Brisbane, Australia, 26 September-1 October 2004. 
Table 1. Low, standard, and high values for the most important mode uncertain parameters.

\begin{tabular}{|c|c|c|c|}
\hline Parameters & $\begin{array}{l}\text { Low } \\
\text { value }\end{array}$ & $\begin{array}{l}\text { Standard } \\
\text { value }\end{array}$ & $\begin{array}{l}\text { High } \\
\text { value }\end{array}$ \\
\hline $\begin{array}{l}\text { Base weed-managed yield for both seasons: } \mathrm{ws}^{\mathrm{a}} / \mathrm{ds}^{\mathrm{b}} \\
\left(\mathrm{t} \mathrm{ha}^{-1}\right)\end{array}$ & $2 / 2.5$ & $5 / 6$ & $8 / 10$ \\
\hline Net sale price of rice crop (US\$ $\left.t^{-1}\right)$ & 167 & 278 & 388 \\
\hline Barnyardgrass seed production/cohort ( $\%$ change) & -20 & 0 & 20 \\
\hline $\begin{array}{l}\text { Maximum barnyardgrass seed production (seeds } \mathrm{m}^{-2} \\
\text { season }^{-1} \text { ) }\end{array}$ & 20000 & 48000 & 70000 \\
\hline $\begin{array}{l}\text { Rice crop competition factor on barnyardgrass: } \\
\operatorname{tr}^{\mathrm{c}} / \mathrm{dr}^{\mathrm{d}}\end{array}$ & $0.4 / 0.2$ & $0.6 / 0.3$ & $0.8 / 0.4$ \\
\hline Real discount rate $(\%)$ & 1 & 6 & 27 \\
\hline
\end{tabular}

${ }^{\mathrm{a}}$ ws: wet season; ${ }^{\mathrm{b}}$ ds: dry season, ${ }^{\mathrm{c}}$ tr: transplanted rice; ${ }^{\mathrm{d}}$ dr: direct-seeded rice

Table 2. Treatment cost and net return differences of manual weeding and herbicide application for direct-seeded rice under different labour costs and weed densities for one cropping season.

\begin{tabular}{|c|c|c|c|c|c|c|c|c|c|c|}
\hline \multirow{3}{*}{$\mathrm{WD}^{\mathrm{a}}$} & & \multicolumn{9}{|c|}{ Labour cost $\left(\right.$ US $\$$ manday $\left.^{-1}\right)$} \\
\hline & & \multicolumn{3}{|c|}{ Current (US\$5) } & \multicolumn{3}{|c|}{ High (US\$11) } & \multicolumn{3}{|c|}{ Very High (US\$17) } \\
\hline & & $\mathrm{MW}^{\mathrm{b}}$ & $\mathrm{HA}^{\mathrm{b}}$ & $\mathrm{D}^{\mathrm{b}}$ & MW & HA & $\mathrm{D}$ & MW & HA & $\mathrm{D}$ \\
\hline 5 & $\begin{array}{l}\text { Treatment cost } \\
\left(\mathrm{US} \$ \mathrm{ha}^{-1}\right)\end{array}$ & 34 & 32 & 2 & 69 & 37 & 32 & 103 & 43 & 60 \\
\hline \multirow{3}{*}{10} & $\begin{array}{l}\text { Net returns } \\
\left(\mathrm{US} \$ \mathrm{ha}^{-1}\right)\end{array}$ & 599 & 595 & 4 & 532 & 556 & -25 & 464 & 517 & -54 \\
\hline & $\begin{array}{l}\text { Treatment cost } \\
\left(\mathrm{US} \$ \mathrm{ha}^{-1}\right)\end{array}$ & 52 & 32 & 20 & 104 & 37 & 67 & 157 & 43 & 114 \\
\hline & $\begin{array}{l}\text { Net returns } \\
\left(\mathrm{US} \$ \mathrm{ha}^{-1}\right)\end{array}$ & 568 & 582 & -14 & 483 & 543 & -60 & 397 & 504 & -107 \\
\hline 15 & $\begin{array}{l}\text { Treatment cost } \\
\left(\mathrm{US} \$ \mathrm{ha}^{-1}\right)\end{array}$ & 74 & 32 & 42 & 148 & 37 & 111 & 223 & 43 & 180 \\
\hline
\end{tabular}




$\begin{array}{llllllllll}\text { Net returns } & & & & & & & & \\ \left(\mathrm{US} \$ \mathrm{ha}^{-1}\right) & 527 & 563 & -36 & 419 & 524 & -105 & 312 & 485 & -173\end{array}$

20

Treatment cost

$\begin{array}{llllllllll}\left(\mathrm{US} \$ \mathrm{ha}^{-1}\right) & 87 & 32 & 55 & 174 & 37 & 137 & 261 & 43 & 218 \\ \begin{array}{l}\text { Net returns } \\ \left(\mathrm{US} \$ \mathrm{ha}^{-1}\right)\end{array} & 502 & 551 & -49 & 382 & 512 & -130 & 261 & 473 & -212 \\ & & & & & & & & & \end{array}$

${ }^{\mathrm{a}} \mathrm{WD}$ : weed density $\left(\right.$ plants $\mathrm{m}^{-2}$ ). Note that this is the weed density present at the time of performing manual weeding or herbicide application in the rice fields. ${ }^{\mathrm{b}} \mathrm{MW}$ : manual weeding, HA: herbicide application, and D: difference between the two treatments.

Table 3. RIMPhil model results with and without herbicide resistance. Results are presented for direct-seeding with high labour cost (US\$17) and optimal weed threshold ( 0.1 plant $\left.\mathrm{m}^{-2}\right)$ over a 20 -year period.

\begin{tabular}{|c|c|c|}
\hline Weed Control & Without resistance & With resistance \\
\hline $\begin{array}{l}\text { Profitable usage of groups A } \\
\text { and B herbicides }\end{array}$ & 10A; 0B & OA; OB \\
\hline $\begin{array}{l}\text { Total usage of other groups } \\
\text { of selective herbicides }\end{array}$ & 20 & 17 \\
\hline $\begin{array}{l}\text { Profitable non-herbicide } \\
\text { weed control options (number } \\
\text { of uses) }\end{array}$ & $\begin{array}{l}\text { - } \text { Reduced tillage (34) } \\
\text { - Full land preparation (6) } \\
\text { - } \text { Certified seeds (40) } \\
\text { - Low seeding rate (40) } \\
\text { - Water management (4) } \\
\text { - Hand weeding at } 15-30 \\
\text { DAS (30) } \\
\text { - Hand weeding at } 31-45 \\
\text { - DAS (25) } \\
\text { - Drumseeder (40) }\end{array}$ & $\begin{array}{ll}\text { - } & \text { Reduced tillage (32) } \\
\text { - } & \text { Full land preparation (8) } \\
\text { - } & \text { Certified seeds (40) } \\
\text { - } & \text { Low seeding rate (40) } \\
\text { - } & \text { Water management (40) } \\
\text { - } & \text { Hand weeding at } 15-30 \\
& \text { DAS (40) } \\
\text { - } & \text { Hand weeding at } 31-45 \\
& \text { DAS (28) } \\
\text { - } & \text { Drumseeder (40) }\end{array}$ \\
\hline $\begin{array}{l}\text { Equivalent annual profit for } \\
\text { years } 1-20\left(\mathrm{PHP} \mathrm{ha}^{-1}\right)\end{array}$ & 64,398 (US\$1,431) & 63,496 (US\$1,411) \\
\hline $\begin{array}{l}\text { Weed density ( } 20 \text { year } \\
\text { average } \mathrm{m}^{-2} \text { ) }\end{array}$ & 0.01 & 0.03 \\
\hline
\end{tabular}

Table 4. RIMPhil model results for with and without herbicide resistance status. Results are for direct-seeding with high labour cost (US\$17) and high weed threshold level (2 plants $\mathrm{m}^{-2}$ ) over a 20 -year period. 
Profitable usage of groups A and $\mathrm{B}$ herbicides

Total usage of other groups of selective herbicides

Profitable non-herbicide weed control options (number of uses)
$12 \mathrm{~A} ; 12 \mathrm{~B}$

40
$0 \mathrm{~A} ; 0 \mathrm{~B}$

40

- Reduced tillage (2) - Reduced tillage (2)

- Full land preparation (38) - Full land preparation (38)

- Certified seeds (40)

- Certified seeds (40)

- Low seeding rate (40)

- Low seeding rate (40)

- Water management (40)

- Water management (40)

- Hand weeding at 15-30 DAS (16)

- Drumseeder (16)

- Hand weeding at 15-30 DAS (40)

- Drumseeder (40)

Equivalent annual profit for years 1-20 (PHP ha-1)

Weed density (20 year average $\mathrm{m}^{-2}$ )

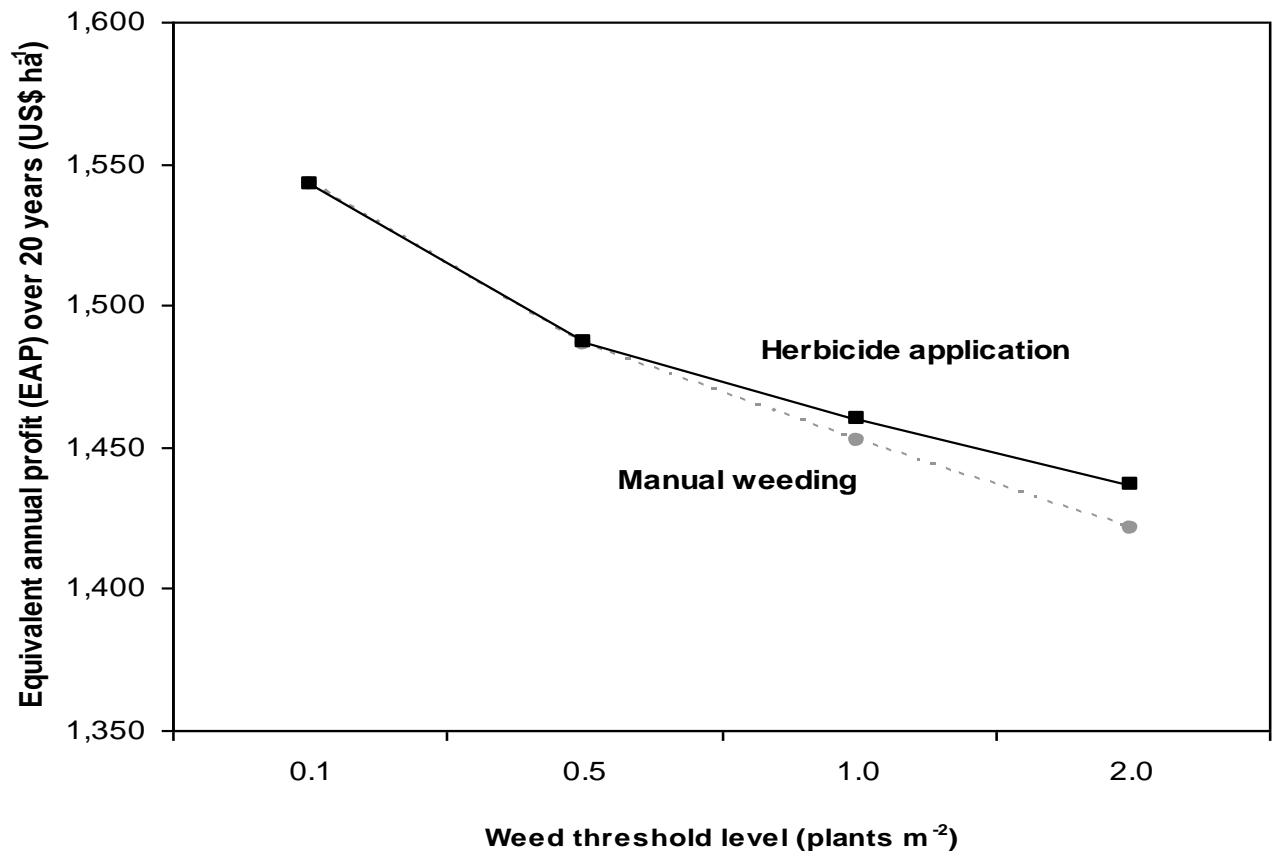

Figure1. Equivalent annual profit (EAP) (US\$ ha ${ }^{-1}$ year $^{-1}$ ) of using manual weeding and herbicide application as weed control options for direct-seeding under current labour cost of US\$5 (base-case scenario) over a 20-year period. 


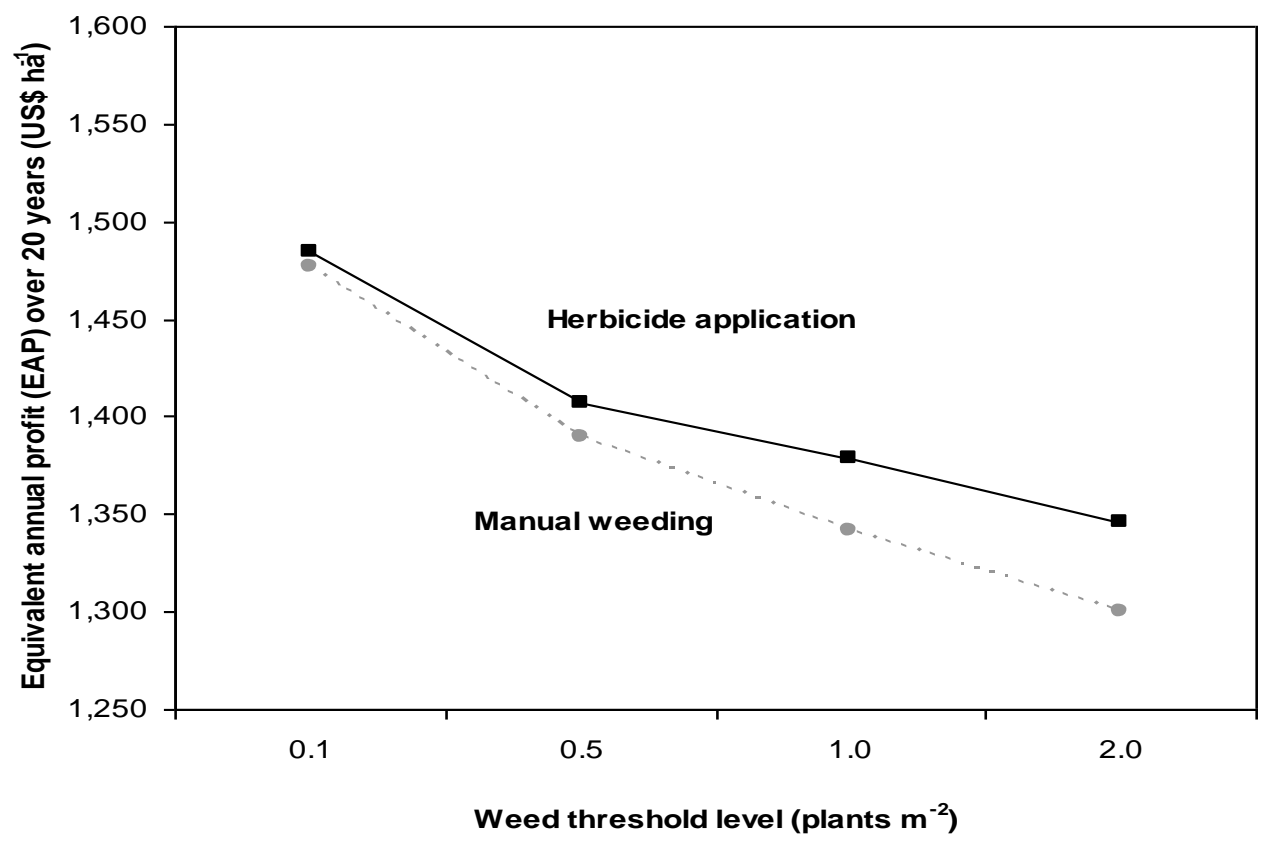

Figure 2. Equivalent annual profit (EAP) (US\$ ha-1 year ${ }^{-1}$ ) of using manual weeding and herbicide application as weed control options for direct-seeding under higher labour cost of US\$11 (100 per cent increase) over a 20-year period.

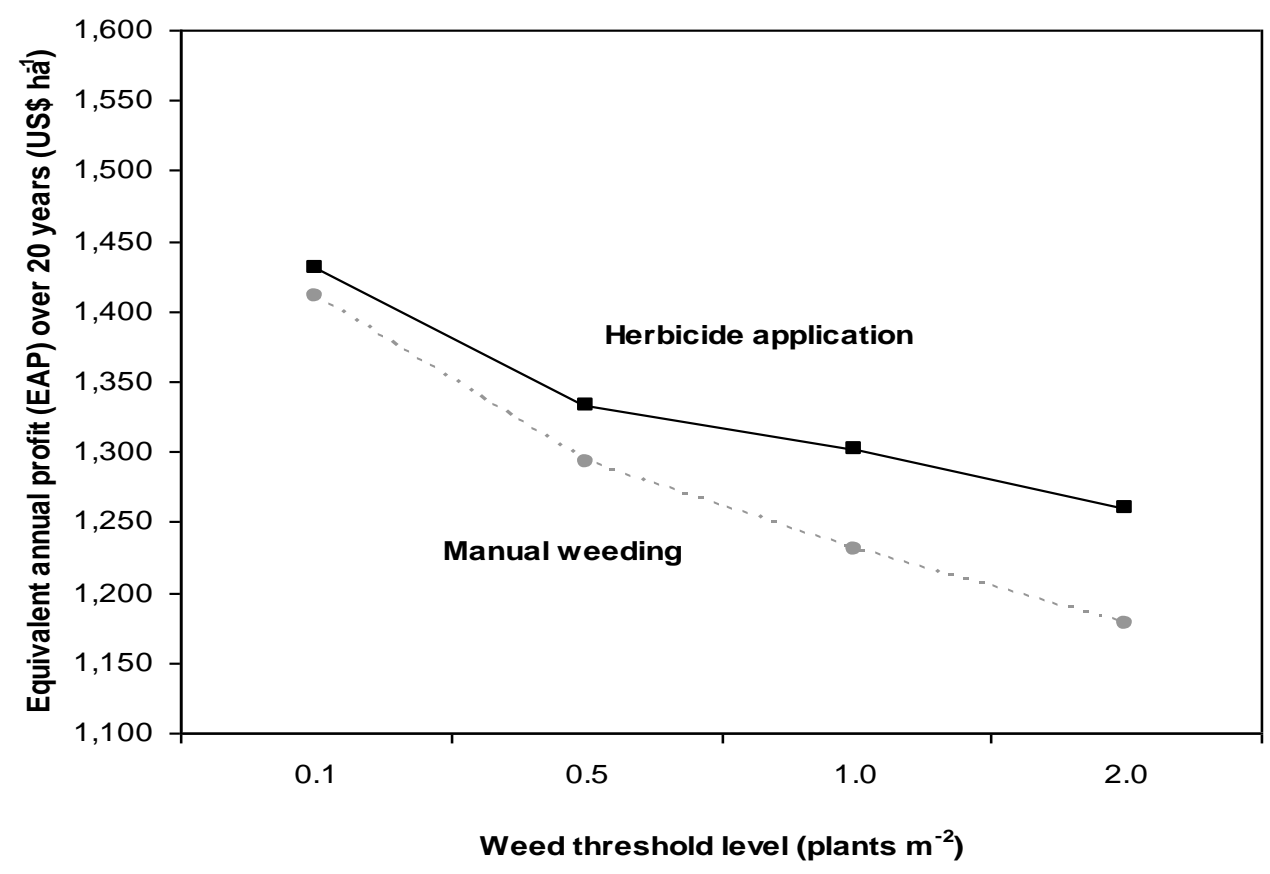

Figure 3. Equivalent annual profit (EAP) (US\$ ha ${ }^{-1}$ year ${ }^{-1}$ ) of using manual weeding and herbicide application as weed control options for direct-seeding under very high labour cost of US\$17 (200 per cent increase) over a 20-year period. 


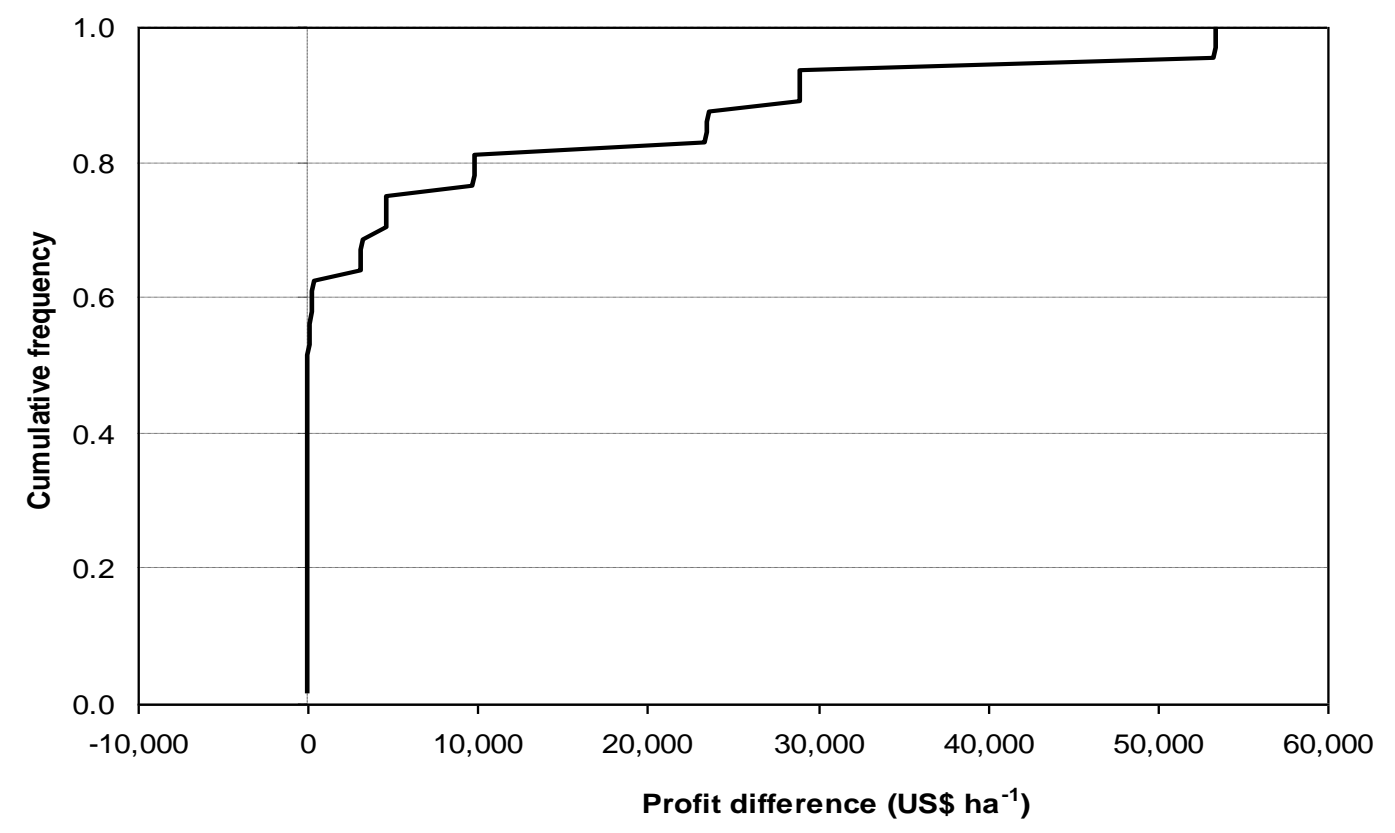

Figure 4. Cumulative distribution function for the profit difference (US\$ ha-1) between herbicide application and extensive use of manual weeding strategies with direct-seeding over 20 years.

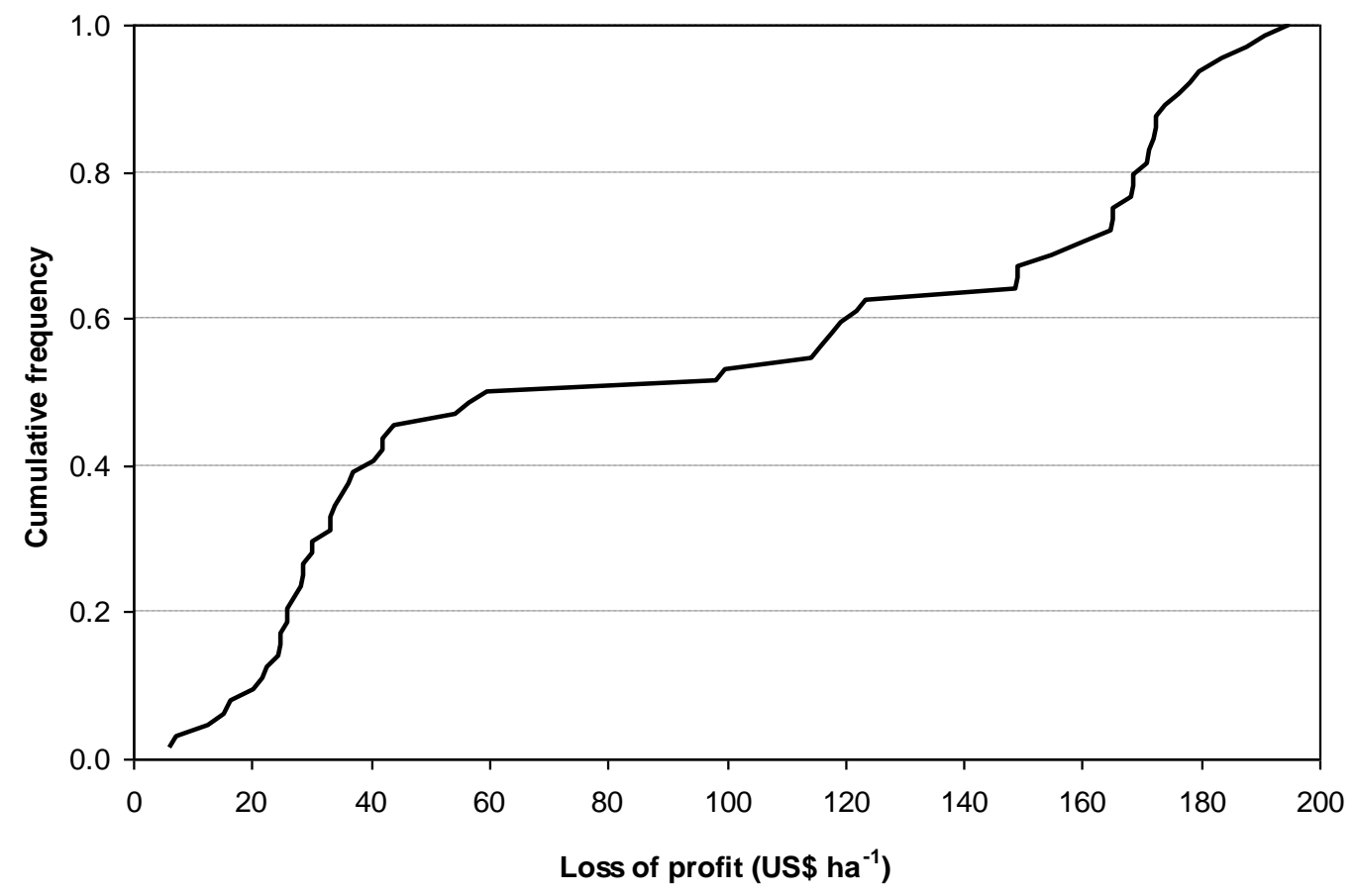

Figure 5. Cumulative distribution function for the profit loss of the existence of herbicide resistance problem with direct-seeding over 20 years. 